\title{
Social capital and access to credit in Kenya
}

\section{${ }^{1}$ Isaac Wachira Mwangi and ${ }^{2}$ Shem Alfred Ouma}

\author{
${ }^{1}$ Research and Policy Analysis Department, Central Bank of Kenya, \\ Box: 60000-00200 Nairobi, Kenya, Phone: +254 20 2863251, \\ Email: mwangiiw@centralbank.go.ke orwamwabz@gmail.com \\ ${ }^{2}$ Research and Policy Analysis Department, Central Bank of Kenya, \\ Email: shemao@centralbank.go.ke
}

\begin{abstract}
Access to credit remains a mirage to a majority in Kenya. Only $39.6 \%$ of Kenya's adult population has access to credit products in Kenya (FSD, 2009). Viewed against a backdrop of growing evidence of rising cost of living, low or no access to credit inhibits both consumption and investment smoothing thus accelerating poverty levels. A bivariate probit model, applied on Fin Access 2009 national survey data revealed that social capital enhances financial inclusion through increased access to informal loans. The study recommends that financial institutions should factor in group affiliation in designing their loan products so as to increase financial outreach.
\end{abstract}

Keywords: Financial access; Informal strand, social capita

\section{INTRODUCTION}

Accessing credit is a major constraint to the development and growth of small and micro enterprises (SMEs) and also to poor rural and urban households. This is mainly due to the behaviour of lenders in terms of hedging against borrowers' risks by demanding collateral, which they lack, and also information asymmetry. Consequently borrowers who are willing to pay prevailing credit interest rates cannot access the funds at those rates because lenders are unwilling to lend to them due to dearth of information about them and lack of collateralisable assets, severely constraining their access to credit. This behaviour is common amongst formal financial institutions. Evidence shows that such borrowers may then be forced to limit their investments to retained earnings (IFC, 2000) thereby restricting enterprises growth and development.

Credit markets in developing countries, especially in Africa including Kenya have evolved mechanisms that circumvent such credit constraints. Borrowers, who are poor in collateralisable assets and for whom lenders have poor information about their creditworthiness have resorted to the use of social capital to improve their accessibility to credit. Social capital refers to connections among individuals that characterize social networks where norms of reciprocity and trustworthiness arise (Putnam 1993). The networks comprise groups of people who interact directly, frequently, and in multi-faceted ways
(Bowels and Gintis 2002, p.420). The networks may involve colleagues, neighbourhoods, friends, professionals, businessmen, gangs and students among others. Social capital in such networks promotes interpersonal trust, provides for sanctions against those who deviate form the norms and serves as a substitute for institutional and legal deficiencies. This is why informal finance thrives in such markets. Clients of informal finance seek no legal enforcement for their activities. The contracts rely more on a sense of moral duty than absolute rights. There are no binding concepts. Nonetheless, they institute effective informal borrowing channels and means of governance based on reputation and relationships and thus promote investments and support economic growth and development. Social capital therefore enables access to private information unavailable to credit markets, monitor members' behaviour and punish individual members who go against the social norms. Sharing information amongst members reduces transactions costs, the sense of belonging facilitates collective decision making and the solidarity and reciprocity that emerge from the networks diminish opportunistic behaviour.

It is important to understand how these social networks enhance credit access to the majority SMEs and the poor rural and urban dwellers in Kenya. The majority of them suffer poor access to formal credit due to lack of assets to secure loans and poor information keeping. For most of them social capital is thought to boost their credit worthiness. This study 
is designed to establish the role of social capital in enhancing access to credit and generate understanding how it works. This knowledge would greatly benefit the design of credit markets that do not constrain credit and starve the development and growth of their business and by extension economic growth. The study utilizes the financial access survey data for 2009.

Kenya's Credit Market: Credit markets represent one side of financial transactions and would not be able to survive on their own without savings, which represents the other side. Without savings, whether foreign, local, private or public there would be no credit. Credit markets short of funds to lend would definitely ration out credit using a variety of criteria. However, credit markets with funds to lend may still fail to do so due to dearth of information about borrowers and poverty of collateralisable assets. The latter has been the case for many a developing country. As a consequence various credit schemes have been designed over time to avail credit to markets, segments of society and clients who suffer poor access or no access to credit markets. In the 70 s and 80 s governments and development partners unveiled credit schemes that targeted particular sectors, enterprises, regions and groups of peoples through Development Banks, MFIs and direct government assistance bilaterally or otherwise. The aim of all these were to provide access to credit to those with poor access in order to boost their economic activities and contribute to the process of economic development. Such schemes have existed and continue to exist in Kenya with the latest such schemes being the women and youth development funds. The two schemes are designed to improve access to women and the youth - two groups who tend to be marginalised from formal credit markets. In similar fashion, the government has also designed a credit scheme for the SMEs to deal with their credit access problems. In Kenya today, according to FinAccess 2009 survey data, 60.4\% do not have access to credit markets. Combined with those that have access to MFIs and SACCOs, more than half of the adult population are excluded from formal bank credit. The situation is worse in rural areas where one in every two adults has never had credit (Fin Access 2009 survey). This implies that the majority access credit informally from ASCAs, RoSCAs, family and friends. Most of these loans are secured through social capital and deviation from the norms guiding them are sanctioned accordingly, substituting for traditional collateral and poor legal frameworks to enforce loan contracts, both of which keep them away from accessing formal credit.

The rest of the paper is organized as follows; Section 2 discusses the literature review, Section 3 gives the empirical framework and data analysis while Section 4 discusses the empirical results. Section 5 gives the conclusions and policy recommendations for the study.

Social capital, defined by Woolcock et al (2000), Fox 1996 and Hanifan (1916) as the norms and networks that enable people to act collectively remains a very important resource, especially in the rural areas. Social capital describes those intangible substances that count for most in the daily lives of people include; goodwill, fellowship, sympathy, and social intercourse among the individuals and families who make up a social unit. Individual contact with neighbors, leads to an accumulation of social capital, which may immediately satisfy one's social needs leading to a social potentiality sufficient to the substantial improvement of living conditions in the whole community.

Social capital enables people to attach greater value in their family, friends and associates that facilitate collective action. Social capital lowers uncertainty and reduces transaction costs thereby fostering economic activity, at the micro level, while at the same time providing a new analytical tool to explain some macro phenomena like rural development differentials.

The level of attachment, social ties and integration is considered to be very high in the rural areas. This could be partly explained by the degree of homogeneity in the economic activities that people engage in, the family ties as well as the cultural practise. One of the major requirements towards credit access in rural areas is investment in social capital. Whereas microfinance institutions will try to extend credit to individuals, it attaches greater value to organised groups. Besides, due to information asymmetry between the households and the financial service providers, rural households may be asked to get people who know them to act as guarantors when applying for funds. This depicts the importance of social capital in rural areas.

Rural financing and particularly microfinance initiatives in most countries rely heavily on social capital in lowering default risks. The success of the programs of microfinance such as Grameen Bank in Bangladesh, BancoSol in Bolivia relies heavily on the notion that borrowers can utilize their social capital to 
overcome many of the problems associated with asymmetric information in credit markets. This includes issues related to adverse selection, moral hazard, state verification, and contract enforcement (Gomez and Santor, 2001). Group membership is an essential tool for screening loan applications and for ensuring that contracts can be enforced (Aryeetey, 2005).

The established social networks help in creating spontaneous mutual insurance mechanisms. Moser (1996) established that those communities endowed with a diverse stock of social networks and civic associations are in a stronger position to confront poverty and vulnerability as opposed to those without such networks. Similar sentiments were echoed by Narayan (1995). Social capital is considered to be very dynamic. Today, acquiring certain jobs requires one to be a member of certain bodies. Some of the organisations sometimes go an extra mile to secure jobs for members. The same applies to economic establishments where certain parcels of land or housing units are sold only to members, a sign that social capital is an important asset. Holzmann and Jorgensen (1999) argue that the poor may have a close-knit and intensive stock of "bonding" social capital that they can leverage to "get by" thus gain access to the available social and economic facilities on offer.

Roth (1997) argues that capitalist enterprises require a specific set of social relationships to blossom in spite of the micro credit receipts. This is because credit is perceived to be just one of the ingredients in the mix of factors necessary for a successful enterprise. Besides most micro credit schemes are motivated by political rather than financial considerations.

Conceptual Framework and Data analysis: This article is based on Marge Sults (2003) where data on the credit status of households is collected and analysed to observe the impact of household characteristics on access to loans. This study goes a step further by including the social capital variable to estimate its impact on access to credit and particularly informal credit. Most rural residents bank on the social ties and the level of intergration in pursuit of their goals. Persons affiliated to certain groupings are often assumed to share certain common characteristics and can therefore attract positive comments from their associates especially on their general conduct and credit worthiness. Estimation of this has been operationalized using a bivariate probit model.
Theoretical Model: McFadden's random utility model (RUM) has been applied in motivating this study where the utility of an individual faced with various alternatives is expressed as follows;

$$
U_{i j}=U_{j} x_{i j}, z_{i j}
$$

Where;

$U_{i j}$ represents the utility derived by individual $i$, from choice of alternative $j$

$x_{i j}$ represents the observed characteristics of individual $i$ and alternative $j$ chosen

$z_{i j}$ represents the unobserved characteristics of individual $i$ and alternative $j$ chosen

This approach incorporates both the observable and unobservable characteristics of individuals and the alternatives they choose.

The Additive Random Utility Model is specified as follows;

$$
\begin{aligned}
& U_{i j} x_{i j} ; z_{i j}=V_{j} x_{i j} ; \beta+\varepsilon_{i j} \\
& \varepsilon_{i j}=U_{i j} x_{i j} ; z_{i j}-V_{j} x_{i j} ; \beta
\end{aligned}
$$

Where;

$V_{j} \quad x_{i j} ; \beta$ is the observable or deterministic

portion of the utility estimated while $\varepsilon_{i j}$ is the unknown utility.

$\beta$ represents the estimated coefficients of the explanatory variables

Assuming that the individual faces two choices, A and $B$ and that the choices are made randomly, $A$ is chosen if;

$$
\begin{aligned}
& V_{A} x_{i A} ; \beta+\varepsilon_{i A}>V_{B} x_{i B} ; \beta+\varepsilon_{i B} \\
& V_{A} x_{i A} ; \beta-V_{B} x_{i B} ; \beta-\varepsilon_{i B}-\varepsilon_{i A} \\
& \text { let } \\
& g x_{i}, \beta=V_{A} x_{i A} ; \beta-V_{B} x_{i B} ; \beta
\end{aligned}
$$




$$
\begin{aligned}
& \eta=\varepsilon_{i B}-\varepsilon_{i A} \\
& {\left[\begin{array}{lll}
U_{i B} & x_{i B}, z_{i B}-V_{B} x_{i A} ; \beta
\end{array}\right]-\left[\begin{array}{lll}
U_{i A} & x_{i A}, z_{i A}-V_{A} x_{i A} ; \beta
\end{array}\right]} \\
& \quad C_{i}^{*}=g x_{i}, \beta-\eta_{i} .
\end{aligned}
$$

Where: $C_{i}^{*}$ is the latent variable which drive one in choosing a certain alternative

$x_{i j}$ and $z_{i j}$ are as defined above.

$\beta$ represents the estimated coefficients of the explanatory variables

$V_{A} x_{i A} ; \beta+\varepsilon_{i A}$ is the utility derived from choice of alternative $\mathrm{A}$ where $V_{A} x_{i A} ; \beta$ is the observable or deterministic portion of the utility estimated while $\varepsilon_{i A}$ is the unknown utility.

$V_{B} x_{i B} ; \beta+\varepsilon_{i B}$ is the utility derived from choice of alternative $\mathrm{B}$ where $V_{B} x_{i B} ; \beta$ is the observable or deterministic portion of the utility estimated while $\varepsilon_{i B}$ is the unknown utility.

$g x_{i}, \beta$ is the observable difference in utilities from choice of alternative $A$ and not $B$.

$\eta$ (Eta) is the unobservable difference arising from the omission of other variables.

The latent variable incorporates both the observable $g x_{i}, \beta$ and the unobservable $\left(\eta_{i}\right)$ differences in utility.

This implies that the choice made by an individual is guided by the difference in utility from the various alternatives available. Individual $i$ is assumed to choose alternative $\mathrm{A}$ if $U_{A}>U_{B}$. The errors $\varepsilon_{i A}$ and $\varepsilon_{i B}$ arise from omitted variables, measurement errors and specification errors arising from the functional choice.

Empirical Model: A bivariate probit model has been used to determine the probability of accessing credit from the informal strand based on the individual characteristics. Both the demographic and socioeconomic characteristics of individuals drawn from the literature review will be analysed in the following model.

$$
C=f\left(L, H H, A, G, E, M, D, Y, S C, A^{2}, I\right)
$$

Where; $C=$ Access to credit

$$
L=\text { Location whether urban or rural }
$$

$\mathrm{HH}=$ Household size

$A=$ Age of the individual

$G=$ Gender

$E=$ Level of Education

$M=$ Marital status

Institutions

$D=$ Distance from the Financial Service

$Y=$ Individual earnings

$S C=$ Social Capital

$A^{2}=$ Age squared

$r=$ Interest charges which also serves as a risk factor

Bivariate Probit estimation: The main issue in this case is to establish the factors that drive access to credit in the informal strand. Use of bivariate probit model is motivated by the correlation between the error terms $\varepsilon_{1}$ and $\varepsilon_{2}$ since the choice of informal credit is conditional on one being banked. The model also bears several desirable characteristics such as ensuring that the estimated probabilities lie between 0 and 1 (Menard, S. 1995, p.13), unlike the linear probability model. Besides, the estimated probabilities are considered to be linear in their parameters, ensuring that an increase in magnitude of an independent variable, will increase or decrease the probability of choosing any of the options or not.

The bivariate probit is specified as follows according to Green (2003); 


$$
\begin{aligned}
& c_{1}^{*}=x_{1}^{\prime} \beta_{1}+\varepsilon_{1}, \quad c_{1}=1 \quad \text { if } c_{1}^{*}>0,0 \text { otherwise } \\
& c_{2}^{*}=x_{2}^{\prime} \beta_{2}+\varepsilon_{2}, \quad c_{2}=1 \quad \text { if } c_{2}^{*}>0, \quad 0 \text { otherwise } \\
& \mathrm{E} \varepsilon_{1}\left|x_{1}, x_{2}=\mathrm{E} \varepsilon_{2}\right| x_{1}, x_{2}=0, \\
& \text { Var } \varepsilon_{1}\left|x_{1}, x_{2}=\operatorname{Var} \varepsilon_{1}\right| x_{1}, x_{2}=1 \\
& \operatorname{Cov} \varepsilon_{1}, \varepsilon_{2} \mid x_{1}, x_{2}=\rho
\end{aligned}
$$

This specification says that $C_{2}$ is observed when $C_{1}{ }^{*}>0$ but $c_{2}^{*}$ need not take on any meaningful value when $C_{1}^{*} \leq 0$

The bivariate normal Cumulative Distribution Function (CDF) is specified as follows.

prob $X_{1}<x_{1}, X_{2}<x_{2}=\int_{-\infty}^{x_{2}} \int_{-\infty}^{x_{1}} \phi_{2} z_{1}, z_{2}, \rho d z_{1} d z_{2}$, otherwise stated as

$$
\Phi_{2} x_{1}, x_{2}, \rho
$$

Differentiation of the above function yields the Probability Density Function (PDF) which gives the marginal effects.

The density function is specified as follows:

$$
\phi x_{1}, x_{2}, \rho=\frac{e^{-(1 / 2)\left(x_{1}^{2}+x_{2}^{2}-2 \rho x_{1} x_{2}\right) /\left(1-\rho^{2}\right)}}{2 \pi\left(1-\rho^{2}\right)^{1 / 2}}
$$

The subscript 2 in the CDF $\Phi_{2}$ and PDF $\phi_{2}$ stands

\begin{tabular}{|c|c|c|c|}
\hline & & & $\begin{array}{l}\text { n (Campbel } \\
\text { and } \\
\text { Mankiw, } \\
\text { 1989) }\end{array}$ \\
\hline Age & $\begin{array}{ll}\text { Age } & \text { of } \\
\text { respondents } & \text { in } \\
\text { years } & \end{array}$ & Positive & $\begin{array}{l}\text { Access at } \\
\text { intermediate } \\
\text { age is } \\
\text { higher } \\
\text { (Zeller, } \\
\text { 1994) }\end{array}$ \\
\hline Education & $\begin{array}{l}\text { This is captured } \\
\text { using highest } \\
\text { education level } \\
\text { attained }\end{array}$ & Positive & $\begin{array}{l}\text { Higher } \\
\text { education } \\
\text { raises } \\
\text { access } \\
\text { (Zeller, } \\
\text { 1994) }\end{array}$ \\
\hline Gender & $\begin{array}{l}\text { 1-Male } \\
\text { (Reference } \\
\text { dummy); } \\
\text { female }\end{array}$ & $\begin{array}{l}\text { Negative for } \\
\text { women }\end{array}$ & $\begin{array}{l}\text { Women are } \\
\text { discriminate } \\
\text { d against } \\
\text { (Mayada et } \\
\text { al, 1994) }\end{array}$ \\
\hline $\begin{array}{l}\text { Social } \\
\text { Capital }\end{array}$ & $\begin{array}{l}\text { Captured using } \\
\text { dummy } \\
\text { variables; } 1 \text {. In a } \\
\text { group } \\
\begin{array}{l}\text { Not in a } \\
\text { group }\end{array}\end{array}$ & Positive & $\begin{array}{l}\text { Group } \\
\text { affiliation } \\
\text { reduces } \\
\text { information } \\
\text { asymmetry } \\
\text { and } \\
\text { substitutes } \\
\text { for tangible } \\
\text { collateral } \\
\text { thus } \\
\text { attracting } \\
\text { lending }\end{array}$ \\
\hline $\begin{array}{l}\text { Marital } \\
\text { Status }\end{array}$ & $\begin{array}{ll}\text { 1-Single } & \text { 2- } \\
\text { Divorced; } & 3- \\
\text { Widowed; } & 4- \\
\text { Married/living } & \\
\text { with Partner; } & \text { 5- } \\
\text { Dont know } & \end{array}$ & Positive & $\begin{array}{l}\text { Based on } \\
\text { the } \\
\text { household } \\
\text { constitution }\end{array}$ \\
\hline $\begin{array}{l}\text { Household } \\
\text { Size }\end{array}$ & $\begin{array}{l}\text { Number of } \\
\text { family members } \\
\text { in household }\end{array}$ & Positive & $\begin{array}{l}\text { Large } \\
\text { families are } \\
\text { less } \\
\text { constrained } \\
\text { (Marge, } \\
\text { 2003) }\end{array}$ \\
\hline $\begin{array}{l}\text { Distance } \\
\text { from Credit } \\
\text { Source }\end{array}$ & $\begin{array}{l}\text { Time taken to a } \\
\text { bank }\end{array}$ & Negative & $\begin{array}{l}\text { Despite } \\
\text { closeness } \\
\text { to credit } \\
\text { source, } \\
\text { households } \\
\text { are still } \\
\text { rationed } \\
\text { (Johnson } \\
\text { and } \\
\text { Morduch, } \\
\text { 2007) }\end{array}$ \\
\hline
\end{tabular}
for a bivariate normal distribution.

Description of variables and theoretical expectation: The table below presents the various variables targeted in this study to explain individuals' choice of credit strand.

\begin{tabular}{|l|l|l|l|}
\hline Variable & Description & $\begin{array}{l}\text { Expected } \\
\text { sign }\end{array}$ & $\begin{array}{l}\text { Explanatio } \\
\mathbf{n}\end{array}$ \\
\hline $\begin{array}{l}\text { Interest } \\
\text { rate }\end{array}$ & $\begin{array}{l}1 \text { for those who } \\
\text { consider interest } \\
\text { rates in banks to } \\
\text { be high, 0 } \\
\text { otherwise. }\end{array}$ & Negative & $\begin{array}{l}\text { High cost, } \\
\text { lowers } \\
\text { access } \\
\text { (GoK, 2006, } \\
\text { Fuchs and } \\
\text { Beck, 2004) }\end{array}$ \\
\hline Income & $\begin{array}{l}\text { Captured using } \\
\text { total expenditure }\end{array}$ & Positive & $\begin{array}{l}\text { Transitory } \\
\text { changes in } \\
\text { income } \\
\text { affect } \\
\text { consumptio }\end{array}$ \\
\hline
\end{tabular}

Data type and sources: The analysis is based on Financial Access, 2009 survey data, collected by the Financial Sector Deepening (FSD) Kenya, in collaboration with the Central Bank of Kenya and the 
Kenya National Bureau of Statistics (KNBS). Analysis is based on the 6243 respondents sampled who are 18 years of age and above, which is the legal definition for adults in Kenya.

Estimation Results: Figure I of appendix B shows that $60.38 \%$ of the total adult population in Kenya is locked out of the credit markets. This creates a clear picture of the level of exclusion given that only $39.62 \%$ of the total population was found to have a loan facility. Figure II shows the distribution of the population with access to loans along the four strands i.e. formal $(7.12 \%)$, formal other $(7.72 \%)$, informal $(68.84 \%)$ and excluded (16.32\%).

\section{Econometric Analysis}

Bivariate probit results: The simple probit results indicated that the probability of accessing credit in Kenya stood at $39.32 \%$ among the adult population. This is in support of the existing literature which states that the level of financial inclusion remains low in Kenya. Table I of appendix A presents results for both the simple probit and the bivariate probit to establish the role of social capital alongside other variables in explaining access to credit in Kenya and particularly among the informal strand which appears to place alot of weight on group membership in averting default risks. Under the assumption that the error terms are normally distributed, the bivariate probit regression revealed that place of residence (rural), household size, distance from a bank, level of income and the squared age variable are negatively related to access to credit. However, the more educated a person is, the more likely it is that the person will be able to access credit. Similarly, elderly and married persons have a positive dependence with access to credit. In terms of significance, with the exception of cluster, education, and the social capital variable, all the other variables namely; household size, age, gender, marital status, distance, income, age squared and interest were found to be significant.

Infinitesimal changes in household characteristics leads to varying changes in the probability of accessing credit from banks. Appendix Table 1, reveals that as age increases by 1 year from a mean of 39.25 to 40.25 , the probability of accessing credit from the informal strand increases marginally by $0.85 \%$. The picture changes with the advancement in age as explained by the age squared variable which indicates a $0.01 \%$ reduced probability over time. Increase in household size by one person reduces the probability of accessing an informal loan by
$0.34 \%$ while a shilling increase in income reduces the probability by $0.0002 \%$. In terms of location, rural residents have a $1.36 \%$ lower probability of accessing informal loans as compared to the urban dwellers. Women were found to have a $3.5 \%$ higher probability of accessing credit from a bank than the male counterparts. Despite this higher probability registered for women, in aggregate terms, more women were credit constrained, which is in conformity with sentiments echoed by Mayada et al (1994) and earlier findings from FinAccess 2009 survey that more women than men remain financially excluded.

In terms of geographical separation from a bank, increase in the distance covered to a bank lowers the probability of accessing an informal loan by $2 \%$. Being in a marriage set up raises ones probability of accessing an informal loan by $3.0 \%$. This is partly explained by the fact that a family is the basic unit of a society held according the marriage institution and is accorded a higher degree of trust.

Many people perceive interest rates charged by commercial banks to be high hence opt for alternative sources of funds. Those who considered bank rates to be high were found to have a $5.86 \%$ higher probability of seeking alternative sources of loans from the informal strand. Social capital which is the main thrust of this paper was found to be statistically significant in explaining loans from the informal strand. Being a member of a certain grouping increased the probability of accessing an informal loan by $1.45 \%$. The more the number of groups one subscribes to, the higher the probability of accessing an informal loan.

Access to credit from the informal strand can be explained using the following model;

Informal loan $=-1.3-0.01$ hh -0.04 location $-0.0005 Y_{i}+0.03 A_{i}+0.11 G_{i}+0.04 S C-$

$$
0.09 M_{i}+0.001 E_{i}-0.06 D_{i}-0.0003 A s q+0.18 I n t+\varepsilon_{i}
$$

The Wald test statistic implies that the parameters or coefficients of the explanatory variables are significantly different from zero, justifying their inclusion in the model. The Wald test assumes a Chisquare distribution. This is also supported by the Likelihood Ratio (LR) test statistic which is also significant.

\section{CONCLUSIONS}

Kenya continues to register improvements in the development of the financial sector. In particular, the country has witnessed phenomenal growth in 
financial intermediation. However, the FinAccess 2009 National Survey indicates that around $60 \%$ of the total adult population is yet to gain access to any form of loan. Only $39.43 \%$ of the total sampled population was found to have access to credit. In 2009, women appeared to have a higher probability of accessing loans from the informal strand as compared to their male counterparts even though this was not reflected in the weighted figures of women with access to loan.

A quadratic relationship was observed between the age of an individual and access to informal loan. The impact of age on access to informal loan became even more significant with advancement in age.

An interesting finding was observed for interest rates. Individuals found a safe haven in the informal markets as captured by the positive marginal effect. Higher interest rate perception on bank loans brings about a substitution effect where individuals resort to informal loans. A similar trend was observed for distance where increase in geographical separation reduced access to loan. Regarding social capital, the higher the number of groups one pledges loyalty to, the higher the probability of accessing a loan.

Policy Recommendations: Having focused on the role of social capital on access to credit and found a positive relationship, the study recommends two main issues. First, credit institutions should factor in the role of social capital in designing credit products since this information helps in reducing information asymmetry between credit institutions and individuals and substitutes for traditional, tangible collateral and hence benefits increased financial inclusion.

Secondly, besides harmonising the information gathered by the various credit reference bureaus, the bureaus should ensure that they obtain borrower information from all relevant sources including informal groups which serve to provide alternative sources of credit from formal providers based on indepth information on borrowers and their web of networks, which is embodied on social capital.

\section{Appendix A.}

Table I: Simple Probit and Bivariate probit Results (Marginal Effects)

\begin{tabular}{|c|c|c|c|c|c|}
\hline \multicolumn{6}{|c|}{ Number of Observations $=6103$} \\
\hline \multirow[b]{5}{*}{ Variable Name } & \multicolumn{2}{|l|}{$\begin{array}{l}\text { Predicted probability } \\
=0.39321906\end{array}$} & \multicolumn{2}{|l|}{$\begin{array}{l}\text { Predicted probability } \\
=0.26742497\end{array}$} & \multirow[b]{5}{*}{$\begin{array}{l}\text { MEAN } \\
\text { VALUES }\end{array}$} \\
\hline & \multicolumn{2}{|c|}{ Log likelihood=3921.7329 } & \multicolumn{2}{|c|}{ Log likelihood $=5306.2926$} & \\
\hline & \multicolumn{2}{|l|}{ LR chi2 $(11)=365.44$} & \multicolumn{2}{|l|}{ LR chi2 $(1)=4239.91$} & \\
\hline & \multicolumn{2}{|l|}{ Pseudo R2=0.0445 } & \multicolumn{2}{|l|}{ Wald chi2(22) $=531.22$} & \\
\hline & Pr choice=1 (dy/dx) & z-stat & $\begin{array}{l}\text { Pr Informal=1 } \\
\text { (dy/dx) }\end{array}$ & z-stat & \\
\hline Location & -0.01362 & -0.81 & -0.01358 & -0.92 & 1.29248 \\
\hline Household size & -0.00395 & -1.43 & -0.00341 & -1.39 & 4.89923 \\
\hline Age $^{-m}$ & 0.017 & 7.73 & 0.008512 & 4.49 & 39.2463 \\
\hline Gender $^{* *}$ & -0.00079 & -0.06 & 0.03492 & 2.93 & 1.58152 \\
\hline Education & 0.0184 & 3.72 & 0.000447 & 0.10 & 3.16615 \\
\hline Maritalstat" & 0.0356 & 5.89 & 0.0296 & 5.56 & 3.16959 \\
\hline Distance" & -0.0335 & -6.26 & -0.02 & -4.26 & 2.89415 \\
\hline Income" & 8.72E-07 & 3.91 & $-1.78 \mathrm{E}-06$ & -6.04 & 14880.5 \\
\hline Social capital" & 0.0168 & 2.05 & 0.0145 & 2.01 & 0.394068 \\
\hline Agesquared" & -0.00018 & -7.90 & -0.0001 & -5.14 & 1799.96 \\
\hline Interest & 0.0744 & 5.27 & 0.058634 & 4.71 & 0.552515 \\
\hline
\end{tabular}




\section{Appendix B}

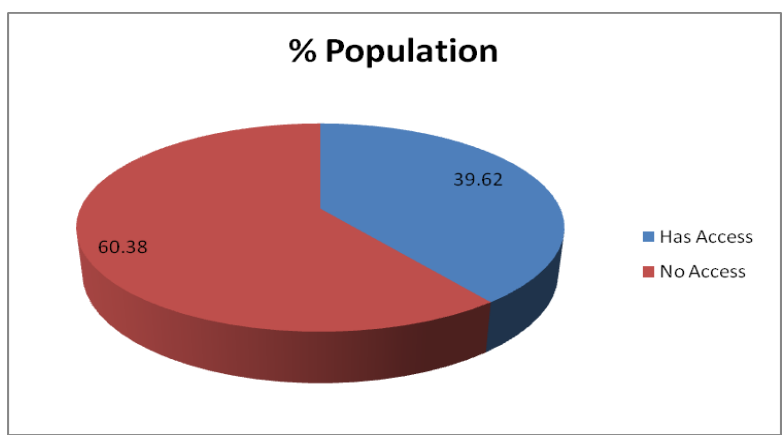

Source: FSD Kenya 2009

Figure I: Status of Access to loans among the adult population in Kenya

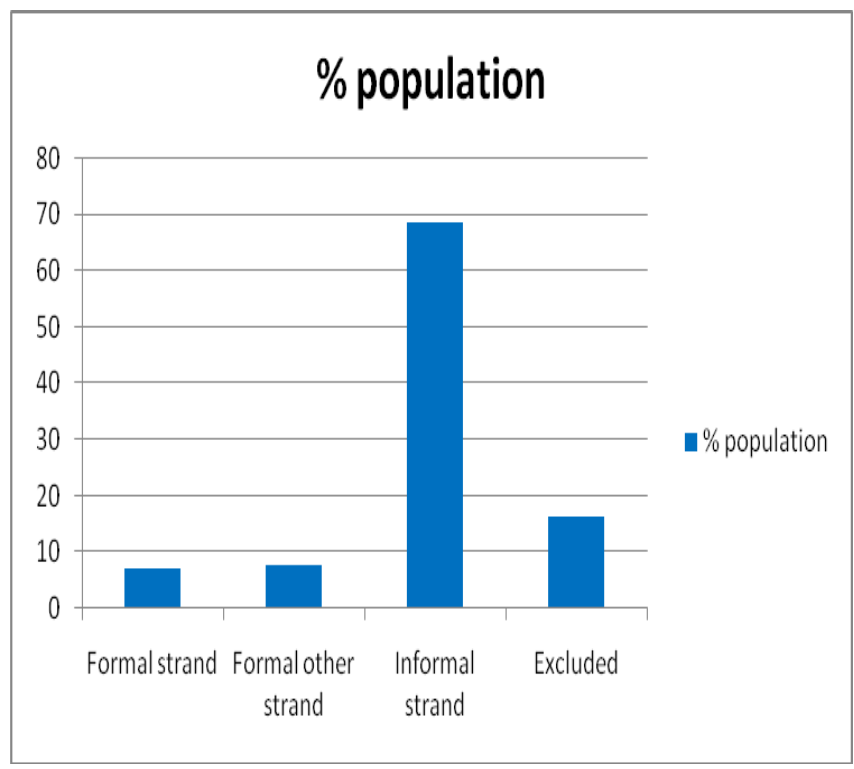

Source: FSD Kenya 2009

Figure II: Loan status across the various strands in Kenya

\section{REFERENCE}

Aryeetey, E.,(2005), "Informal Finance for Private sector Development in Sub Africa",Journal of Microfinance 7(1):13-38

Drake, D. and E. Rhyne, Eds. (2002). The Commercialization of Microifnance: Balancing Business and Development. Bloomfield, CT, Kumarian Press.

Financial Sector Deepening (FSD) and Central Bank of Kenya. (2009). FinAccess National Survey 2009

Fox, Jonathan, 1996. "How does civil society thicken? The political construction of social capital in rural Mexico," World Development, Elsevier, vol. 24(6), pages 10891103

Fukuyama, Francis. 1995. Trust: the Social Virtues and the Creation of Prosperity.

New York: Free Press.

Gomez, R. and Santor, E., 2001. Membership has its privileges: the effect of social capital and neighbourhood characteristics on the earnings of microfinance borrowers. Canadian Journal of Economics 34 (4) pp. 943-966

Hanifan, L. J. (1916). 'The rural school community center', Annals of the American Academy of Political and Social Science 67: 130-138.

Holzmann, R. and Jorgensen, S. (1999), Social Protection as Social Risk Management: Conceptual underpinnings for the Social Protection Sector Strategy Paper, Social Protection Discussion Paper No. 9904, The World Bank (Washington, D.C.).

International Finance Corporation (2000), China's Emerging Private Enterprises: Prospects for the New Century, World Bank, Washington, D.C.

Liu, W. and Spanjers, W. (2005), Social Capital and Credit Constraints in Informal Finance, Discussion paper, Faculty of Arts and Social Sciences, Kingston upon Thames, Kingston University, UK.

Marge Sults, (2003). Banking sector development and credit constrained households in Estonia

Menard, S. (1995), Applied Logistic Regression Analysis: Quantitative Applications in the Social Sciences, Sage Publications, Inc., Thousand Oaks.

Moser, C. 1996. Confronting Crisis: A Comparative Study of Household Responses to Poverty and Vulnerability in Four Poor Urban Communities. Washington, DC: The World Bank. 
Am. J. Soc. Mgmt. Sci., 2012, 3(1): 8-16

Narayan, Deepa. 1995. "The Contribution of People's Participation in121 Rural Water Projects." ESD Occasional Paper Series No. 1. WorldBank, Washington, D.C

Putnam, R. D. (1993), The prosperous community: social capital and public life, in the American Prospect, 4:13

Rosemary Atieno (2001), 'Formal and Informal Institutions' Lending Policies and Access to Credit by Small-Scale Enterprises in Kenya: An Empirical Assessment'. AERC research papers.

Roth James, 1997. The limits of micro credit as a rural development intervention. Institute for Development Policy and Management, Manchester University.
Susan Johnson, Markku Malkamaki and Kuria Wanjau (2005), "Tackling the Frontiers of Micro Finance in Kenya: The Role of Decentralised Services". Decentralised Financial Services

Thierry van Bastelaer (2000), 'Does social capital facilitate the poor'saccess to credit'? Social capital initiative, working paper no. 8

Woller, G. (2002). "The promise and perils of microfinance commercialization." Small Enterprise Development 13(4): 12-21.

Woolcock, Michael, and Deepa Narayan. 2000. "Social capital: Implications for development theory, research, and policy." The World Bank Research Observer 15: 225-249. 